\title{
Friendships of Virtue, Pursuit of the Moral Community, and the Ends of Business
}

\author{
Richard M. Robinson ${ }^{1}$
}

Received: 28 March 2016/Accepted: 21 July 2016/Published online: 3 August 2016

(c) The Author(s) 2016. This article is published with open access at Springerlink.com

\begin{abstract}
It is argued here that business firms can and do provide an incubator that enables the Aristotelian category of friendships of advantage to develop into friendships of virtue. This contradicts other literature that views acquaintances of utility as the business norm, and expresses pessimism concerning more advanced virtuous development of friendship within the business firm. It is argued here, however, that this virtuous development is integral to the Kantian social aim of pursuing a moral community, an aim which declares the appropriate moral motivation for business, and that certainly should incorporate a role for developing virtuous relations as a component of that pursuit. An atmosphere that encourages the development of relations of virtue is feasible, exists in real business, and is optimal for pursuit of moral business communities.
\end{abstract}

Keywords Kantian moral motivation - Pursuit of moral community in business - Aristotelian friendships of virtue

\section{Introduction}

The three-part title of this article suggests interactions between a category of social relations, moral motivation, and the ends of business organizations. It is a trite observation that modern society is built around the social institutions of family, church, civic, and business organizations, with the latter certainly not being the least in either amount or importance of activity. This places business in a

Richard M. Robinson

robinson@fredonia.edu

1 Department of Business Administration, SUNY Fredonia, E340 Thompson Hall, Fredonia, NY 14063, USA significant role for facilitating friendly social interactions, for which Sommers (1997), Koehn (1998), and Cooley (2002) suggest that only friendships of advantage (or utility) are likely to result. Below, I argue against this view of business-related friendships. I argue that friendships of virtue are facilitated by business; that they can be, and likely are important for facilitating the pursuit of a moral business community. An outline of my argument is presented immediately below. The body of this article supports each of these three points in greater detail.

- Business firms are communal activities. The proper moral motivation for business is to pursue a moral community as in Kant's third formula for the categorical imperative. If followed, this motivation focuses the business person's attention away from the personal consequences of potential immoral acts, and towards a commitment to the business community at hand and the consequences for it. For this community focus, the moral motivation is likely to be more effective, certainly for those who have sympathy for the potential suffering of business colleagues and constituents, suffering that might result from the moral failings of others. ${ }^{1}$ Actual full achievement of the moral community, rather than the pursuit, cannot be the point because the knowledge that this achievement is unlikely could lead to discouragement, and therefore abandonment of the motive. It is the pursuit of the Kingdom of Ends (in Kantian terminology) that is important here. This previously unexplored view of the appropriate

\footnotetext{
${ }^{1}$ Kant, of course, insists that respect for the moral law must be the moral motive, a respect that does not rely on sympathy or consequences. See the next section where consequentialist notions in support of the pursuit of the moral community are explored and compared with the pure Kantian notion.
} 
motivation for business is offered as the first of three contributions provided by this article.

- Friendships are part of any community including that of business. The intense working and lasting relationships found within business potentially facilitate the development of friendships of utility, but also friendships of virtue in the Aristotelian sense. The former category of friendship may develop into the latter among those motivated to pursue a moral community as referred to above. Such friendships reinforce the morality of one another, and also promote a wider set of, and commitment to, positive duty, and can become essential parts of any business community. In addition, business people with friendships of virtue are likely to be reluctant to alienate those relations through their own potential moral lapses. Previous explorations of business friendships left those of the virtue category barely explored. The elucidation presented here is therefore the second contribution of this article.

- Because of the above, the moral motivation of the pursuit of the moral community within business, together with developed friendships of virtue, are likely to interact so as to strengthen the morality of business. In effect, the development of friendships of virtue potentially and partially operationalize the pursuit of the moral community for business. ${ }^{2}$ This conclusion represents the third contribution of this article.

To explore these interrelated issues in depth, the article first addresses the issue of moral motivation, both in a general social sense and in the specific sense applicable to business. For this, as indicated above, the "Moral Motivation" section reviews a Kantian approach, but from a somewhat different perspective than previously addressed by the literature. Following this, in the "Classic and Recent Applicable Notions of Friendship, Sociability, and Moral Community" section the article examines the role of friendships in business; "The Pursuit of Business as a Moral Community, Friendships of Virtue, and Duty" section examines the role that relations of virtue play in enhancing the scope and commitment to positive duty in business; the "Relations of Virtue and Avoidance of Evil in Business" section examines the role of these relations in avoidance of evil in business. The last section summarizes the roles that development of virtuous relations can play in operationalizing the pursuit of a moral business community.

\footnotetext{
$\overline{2}$ Adoption and communication of moral maxims, including appropriate adjustments to evaluation and reward systems being the additional operationalizing parts.
}

\section{Moral Motivation}

Immanuel Kant argued that the moral law should be respected and followed because it is self-imposed. (See the Kant 1785, "First Section," and also Hill 1992, p. 6, Korsgaard 1996, pp. 22-23, and Wood 1999, p. 32.) This argument, however, appears less than complete, and rather inadequate as a motivation for morality. Why should someone self-impose moral duty, and why should it be respected? It is argued below that the answers to these questions have profound consequences for the conceptualization of business ethics.

These answers also properly pertain to the broader question of the potential morality and benefits of a competitivemarket economy. This "broader question" is manifested by the apparent contradiction between Adam Smith's ethical philosophy as expressed in The Theory of Moral Sentiments (1759), and the egoistic agent of the invisible-hand as expressed in Wealth of Nations (1776). (See White 2011, pp. 114-115.) White (2010) argues that Smith did not favor egoism. Since agents know their self-interests, Smith pointed out that markets can operate with a degree of efficiency, but Smith did not argue that they should operate that way. The moral behavior of business participants still determines the extent that market interactions fulfill societal interests. It is argued here that the moral motivation of pursuit of a moral business community determines this behavior.

Immanuel Kant's ethical theory was published within a twenty-one-year span after Smith's Wealth of Nations. This ethical theory is founded on Kant's categorical imperative process (CI process) with its three formulae. (See below and also see Sullivan 1994.) In Kantian analysis, it is essential to recognize that this CI process is both a method of forming personal maxims, and after social discourse, of forming political commitments to these maxims. The three formulae are, as Kant argued, interrelated where one logically follows from the other. They are usually viewed as logical restatements of each other. It is argued below, however, that they are more unique than mere "restatements." Each formula plays a particular role in the CI process. They may logically follow from one another, but they still express differing principles necessary for the process to function.

To this end, it is argued below that the third formula of the CI properly specifies ethical motivation: Act so as to pursue the Kingdom of Ends of a moral community ( $K$ of $E$ ). This point concerning ethical motivation has not been previously emphasized, but only indirectly alluded to, and therefore not clearly presented in previous literature. ${ }^{3}$ This,

\footnotetext{
3 One assumes that since Kant emphasized "respect for the moral law" as the motivation, Kantians avoided turning to the third formula as playing this role. Yet that is how the third formula was utilized in ethical explorations.
} 
and only this, socially and personally justifies a rational respect for the moral law; the other nonsocial reasons being egoistic, that is either religious (other-worldly as in the pursuit of a heavenly reward), or the pursuit of virtue for the purpose of achieving personal contentment. In fact, the third formula is the reason for the moral law's existence. Pursuit of the $\mathrm{K}$ of $\mathrm{E}$ is the logical-political reason we selfimpose our moral maxims, i.e., we pursue a moral community in both general society, and in the context of our particular business and economic relations. Indeed, this motivation is communal in that it is a moral commitment to all the communities one belongs to. ${ }^{4}$ Business is one of the most important (next to family and friends) of these communities, or at the very least it is extraordinarily ubiquitous. This non-egoistic motivation should therefore be emphasized in explorations of business ethics.

What is meant by Kant's claim that the moral motivation should be respect for the moral law? Why should respect be the paramount argument? The reason offered is that through the categorical imperative process, the moral law is self legislated. The implication is that once the moral law is logically imposed, a violation would be against the agent's own logic, i.e., illogical, but why impose this moral law on one's actions to begin with? The possible reasons are consequentialist, either personal or social consequentialist.

The first non-religious motive for this respect is egoistic as presented in the Socratic dialogue Gorgias: moral violations cause disharmony with oneself (with one's conscience), hence they are self destructive. (See Arendt 1978, p. 181.) The second non-religious reason is that moral violations attack the community.

"As citizens, we must prevent wrong-doing because the world in which we all live, wrong-doer, wrongsufferer, and spectator, is at stake; the city (community) has been wronged." (Ibid, p. 182, parentheses added.)

It is the second consequentialist reason that is expressed by pursuit of the moral community in business, i.e., an application of Kant's third formula of the categorical imperative.

Bowie particularly argued the applicability of the third formula for business.

"Loosely put, this formulation of the categorical imperative says that you should act as if you were a member of an ideal kingdom of ends in which you were both subject and sovereign at the same

\footnotetext{
${ }^{4}$ Wood (1999, pp. 301-302) makes the point that the opposite of an egoistic motive is a "pluralistic" motive, the latter being "cosmopolitan," i.e., "citizen of the world."
}

time. But what did Kant mean? Kant recognized that human beings interacted with other human beings (ends). Thus, the arena of interactions was called a "kingdom of ends." A business organization, like any other organization, is composed of individual persons and since persons are moral creatures, the interactions of persons in an organization are constrained by the categorical imperative." (Bowie 1999, pp. 87-89)

Although this $\mathrm{K}$ of $\mathrm{E}$ is an unreachable ideal, its pursuit motivates notions of duty usually founded in Kant's first two formulae of the CI. ${ }^{5}$ This $\mathrm{K}$ of $\mathrm{E}$ goal should be intended, of course, to conceptualize the pursuit of a wide moral society, but it should also conceptualize a single organization (a business organization) as a union with harmonious pursuit of moral maxims with implied duties. As reviewed below, the profit motive of classical economics must be properly interpreted as subsumed within the broader pursuit of a moral business community, and this view is best founded on Kant's CI process. ${ }^{6}$

Bowie (1999) does not explicitly argue that the third formula should be considered the motivational formula, but following Hill (1992), he argues that the third formula provides a "heuristic model of the appropriate moral attitude to take when deliberating from basic moral values to moderately specific principles." (Hill 1992, p. 244) The "appropriate moral attitude" is close to stating "motivation" for action. Bowie continues, however, to state that these "moderately specific principles" provide the afore mentioned "heuristic," that in particular "... a firm should be managed so both the organizational rules and the organizational structures are neither coercive nor deceptive and are supportive of meaningful work for employees. ... Finally, the organizational rules and structures must be fair to all stakeholders." (Bowie 1999, p. 89)

Bowie's "heuristic" is not meant to be a statement of moral motivation, but rather a design of moral codes that guide a firm. It is argued below that Bowie's vision of the $\mathrm{K}$ of $\mathrm{E}$ is incomplete. This "pursuit" requires more than the "heuristic" mentioned above. It not only requires a motivational view for forming and following a business's maxims, but as a central feature this view also benefits from the formation and utilization of friendships of virtue. The benefits of friendships within business have been previously addressed by Sommers (1997), and Koehn (1998), but not within the context of the utilization of

\footnotetext{
5 Notions of duty can be derived from each of the formulae of the CI, and according to Kant's argument, each formula is implied by the others. Note that Kant (1785, "Second Section") used the first formula to derive an illustrative set of four maxims with implied duties.

${ }^{6}$ Brennan (2012) argues that for-profit business can be consistent with the exercise of civic virtue. This is a non-Kantian approach.
} 
friendships of virtue for operationalizing the pursuit of the $K$ of $E$. The desirability of this utilization is emphasized here.

This analysis begins with a review of classic notions of moral community which lay the foundation for the Kantian view. These notions include Aristotelian and Stoic ideas of virtuous social interaction relevant for proper exploration of such a community. It is one thing to be motivated to pursue a moral community, it is another to form the necessary maxims for this pursuit, and still another to operationalize this pursuit. The following section pertains to this operationalization.

\section{Classic and Recent Applicable Notions of Friendship, Sociability, and Moral Community}

Aristotelian virtue ethics is founded on individual pursuit of "eudaimonia"-literally "having a guardian spirit," but generally interpreted as having a flourishing life. Its usual definition is "having an objectively desirable life, universally agreed by ancient philosophy to be the supreme good." (Taylor 1995, p. 252.) This is not the modern philosophical concept of happiness as in a subjectively satisfying life. The objectively desirable life, i.e., the pursuit of the good, is the aim of virtue ethics where SocraticPlatonic and Stoic notions of virtue are posed as possibly sufficient for this objective. ${ }^{7}$

Kant posed that our non-egoistic-consequentialist moral maxims should be independent of our search for personal wellbeing. Taylor points out, however, that a philosophy of primacy for eudaimonia does not imply egoism (since altruism may be a constituent of eudaimonia) or even narrow consequentialism (since the virtuous moral life is viewed as absolutely required for eudaimonia). (See Taylor 2000, p. 260.) Hence the supposed gulf between Kantian and eudaimonist theories need not be real. I argue below that properties of virtue ethics are necessary for the Kantian pursuit of a moral community. How do we envision this pursuit? Virtue ethics, I argue, plays an important role in this pursuit.

\section{Friendships of Virtue}

Should Aristotle's notion of friendships of virtue be considered a key component of the pursuit of a moral community within business? Cooley (2002) and Sommers (1997) argue that the business community does not include such friendships. Koehn (1998), however, argues somewhat differently, i.e., that such relations might develop in

\footnotetext{
7 Aristotle adds possible good fortune and external goods as necessary additional factors. (Ibid, p. 252).
}

business. These arguments are reviewed in this section along with a more optimistic view of their existence and possible necessity.

In Aristotle's Nicomachean Ethics (NE) (1976), business relationships are categorized under "civic" relationships, which are essential for human good (eudaimonia or flourishing life). All of these civic relations are classified under the rubric of friendships where there are three types listed (NE: 1156 a 7-1157 b 1):

- Friendships based on pleasure seeking, such as those involving recreation of various sorts,

- Friendships based on mutual advantage,

- Friendships based on recognition of moral goodness, also termed "perfect friendships," or "friendship of virtue," or "friendships of character." (See Cooper 1980, Chap. 17, p. 304)

We typically consider the second classification, "friendships based on mutual advantage," as applying to business relations. (See Sommers 1997.) I suggest, however, that we should consider these Aristotelian categories as overlapping, although possibly of unequal benefit between the parties. In business, an ideal is to have friendships based on "recognition of moral goodness" within management. These include friendships between lower and upper management with the latter exhibiting moral leadership, or among managers of similar levels of responsibility with each encouraging and reinforcing the moral character of the other.

As specified in NE, friendship involves wishing for the good of the other party provided this is at least somewhat reciprocated. (Ibid, p. 304) Friendships of moral virtue may develop when two people, having spent time together to know one another's character, use this knowledge to develop trust and love for one another because of their good human qualities. (NE: 1156 b 25-29, and 1156 a 3-5, and $1156 \mathrm{~b}$ 12-17) For our purposes, it is important to note that friendships of advantage can be based on mutual benefit which given time can also emerge into either of the other classifications, or both. This is also an argument presented in Koehn (1998). ${ }^{8}$ In particular, starting with a quote from Aristotle, Koehn observes:

"And virtue friendships begin in decency. The friendship of decent people is decent, and increases the more often they meet. And they seem to become still better from their activities and their mutual correction. For each molds the other in what they approve of." (NE, 1172a 10-14) If you treat me

\footnotetext{
${ }^{8}$ Koehn (1998) argues that friendships of virtue are rare in business, but offers no argument or evidence in support. The author, however, has observed such relations as common in business. See below for some suggested examples.
} 
decently in negotiations, I am more likely to reciprocate and vice versa. We will both, as the saying goes, "rise to the occasion" and make each other better as a result. So friendships of utility (advantage) play an important role in teaching basic social skills, in building community and in preparing people for more challenging friendships." (Koehn 1998, p. 1758)

Friendships of virtue rely on "love of the other for the other's sake" (NE, 9.viii), and may well develop within business because of the intense and lasting cooperation and interactions required. This argument is developed in this section.

A relevant question for our problem at hand is, "What is the value of having friends?" Aristotle's answer is that the flourishing life involves and requires friends, and also requires service to them out of "unself-interested goodwill." (NE 9.iv and 9.ix, and in Cooper 1980, Chapter 17, p. 318) A man's friend is to him a "second self" (NE: 1213 a 10-26) "to live with and share in discussion and thought with-for this is what living together would seem to mean for human beings, (as contrasted with merely) feeding in the same place as with cattle." (Parentheses added.) (NE: $1170 \mathrm{~b}$ 10-14) This "living with" can also be reinterpreted as "working with" since management typically involves intense, ongoing, and purposeful interaction of the sort that can exceed the tenure and intensity of non-business relations. These morality reinforcing relationships of virtue may be necessary for the pursuit of any semblance of a moral community within the civic relation of business. If these relationships are not absolutely necessary for the pursuit of the moral community then surely they would assist in such a pursuit. Any organization we could envision as pursuing a moral business community would likely exhibit at least some of these friendships, probably would exhibit widespread friendships, and would desire to encourage the development of these virtuous relations within it.

Business effectiveness and efficiency requires (a) engaging those with sufficient background-level general knowledge necessary for a reasonable expectation of enabling the firm to prosper, (b) investing time and other resources in those so engaged so that they develop the specific knowledge required for the success of the business, and (c) encouraging those engaged and invested into maintain long-term relations with the firm so that the business is successful. ${ }^{9}$ Friendships of virtue are more valuable for the firm than friendships of advantage both

\footnotetext{
${ }^{9}$ Specific knowledge can only be transmitted from one agent to another at high cost. It is relevant for allocation of decision rights and responsibilities within the firm, and necessary for effective firm functioning. See Jensen (2000, p. 143), and also Brickley et al.
}

because of intrinsic reasons (explored immediately below), and for the former category's ability to encourage the longlasting relations that are beneficial to business success.

Aristotle's idea of the development of friendships of virtue is germane to our exploration. It is one of a dynamic that reinforces and builds among moral friends.

"For friendship is a kind of partnership, and a man stands in the same relation to his friend as to himself, and since the consciousness of his own existence is desirable, the consciousness of his friend's must be the same. They seem to become better men by exercising their friendship and improving each other; for the traits that they admire in each other get transferred to themselves. Hence "from good comes goodness." (NE, 9.xii.)

Another view of what Aristotle had in mind is that a "pleasant self awareness is only satisfactorily obtained through the awareness of a friend and his activities." (Cooper 1980, p. 319) Stewart (1892) eloquently describes this relation:

"He has a sympathetic consciousness of the actions of his friend-of actions which are still in a sense "his own" ... In other words, it is in the consciousness of the existence of another that a man becomes truly conscious of himself." (p. 392)

This might all appear to describe pleasant and relaxed relations between friendly philosophers, but it can also apply to the intense and active relations of business. Awareness of the moral actions of fellow managers helps to place one's personal actions in context for judgement, self reflection, and refinement. The essence of Aristotle's analysis is that "the self sufficing man will require friendship in order to know oneself." (Cooper 1980, p. 320) Here, the notion of "self sufficiency" implies personal characteristics once deeply ingrained and sort of permanently present, will be exercised as a natural tendency. The development of this "self sufficiency" is the purpose of virtue ethics. ${ }^{10}$

How is this position of requiring friends of virtue in order to know oneself justified? Aristotle's argument begins with notions of eudaimonia, i.e., "the flourishing life consists essentially of morally and intellectually excellent activities." (Ibid, p. 329) "A human being cannot have a flourishing life except by having intimate friends to whom he is attached precisely on account of their good qualities of character and who are similarly attached to him: it is only with such persons that he can share the moral activities that are most central to his life." (Ibid,

Footnote 9 continued

(2007), for an extensive review of the roles of general and specific knowledge for firm success.

${ }^{10}$ Annas (1993), makes this point throughout her treatise. 
p. 330) This is the reason for the "second self" mentioned above. This Aristotelian notion goes beyond the judgement-development and refinement benefits of friendship. It involves notions of enhancing contentment and joy as supported and reinforced by the moral community of similar friends of virtue. This certainly describes the ideal of a moral business, i.e., a union of intimate friends one can rely on because of their good qualities.

Cooper continues, however:

"To know the goodness of one's life, which he reasonably assumes to be a necessary condition of flourishing, one needs to have intimate friends whose lives are similarly good, since one is better able to reach a sound and secure estimate of the quality of life when it is not one's own. This involves wanting the other to prosper, and to know the moral virtue of another, one must know them carefully over time." (Ibid, p. 330)

Full development of friendship, even within the business community, requires knowing "the moral virtue of another" as a reinforcement of one's own moral virtue. Only actual participants in friendships of virtue could adequately testify about any dynamic interaction with second selves that ultimately leads to virtuous growth. A partial history of business friendships that might warrant the friendship of virtue classification would need to rely on biography for evidence. From these sources I offer the following possible examples without elaboration:

- Wilbur and Orville Wright. (See McCullough 2015.)

- Kelly Johnson and Ben Rich of Lockheed's Skunk Works fame. (See Rich and Janos 1994.)

- Edsel Ford and Charles Sorensen of the establishment of the WWII Willow Run B-24 Liberator plant. (See Baime 2014.)

- Andrew Carnegie and his mentor Thomas Scott. (See Josephson 1962, and Wikipedia.)

- Ben Cohen and Jerry Greenfield of Ben and Jerry's Ice Cream. (See Lager 1994, and Wikipedia.)

- Bill Gates and Paul Allen of Microsoft and philanthropic efforts. (See Allen 2011, and Wikipedia.)

It is also important to note that besides the friendships described above, moral communities contain some degree of beneficent action among constituents. To pursue a moral community means to pursue this beneficence among other duties. Such pursuit can enhance the classical friendships described by Aristotle whether for advantage or virtue, and friendships are surely facilitated by these actions whether because potential friends are cooperating in this beneficence, or because one of the parties benefits from it, and so is drawn into the relationship. The true pursuit of happiness (eudaimonia) in the classical sense of Aristotle and the
Stoics, is to pursue such relationships of which more is explored by Kant. ${ }^{11}$

Business interactions are typically viewed as between only acquaintances which have a high degree of social distance, but they are actually based on trust. Because of this, as explored above, these acquaintances can develop into friendships of advantage, and perhaps ultimately friendships of virtue. The relevant question concerns "What factors can interrupt this development process?" An answer is provided by Kant's anthropological analysis of human nature.

\section{Unsocial Sociability and Friendships}

Are friendships of virtue necessary to overcome what Kant termed unsocial sociability? Kant assumes that all rational action is teleological, i.e., it pursues some ends which include communally coordinated action that pursues a communal end as in the business firm. (See Wood 1999, p. 162.) A firm is fundamentally a community among those who we assume rationally and voluntarily accept a system of maxims for allocating decision rights, responsibilities, and compensation rewards for an economic purpose. For example, these decision rights and responsibilities include the systems for deciding which long-term capital expansion projects to accept, which marketing strategies to adopt, which employee development initiatives to undertake, and other policy undertakings. By "rational acceptance" I mean that the agents involved either participate in deciding this allocation, or/and are convinced that this allocation accords with their own reflective consent. An example would be an employee who accepts her/his work-related assignment. Otherwise we must assume that constituents would not voluntarily play a role in this firm. The point is made by Bowie (1999, pp. 88-89) that in the Kantian CI process, the maxims of the firm must be publicly formed and accepted by all engaged agents. This is basic Kantian analysis in that it excludes deception and coercion.

Kant's empirical anthropology analyzes humanity's unsocial sociability, i.e., our tendency to resist and ultimately frustrate the efforts and intended ends of others. (See Kant 1784, vol. 8, p. 21, and Wood 1999, p. 213, and White 2011, p. 112.) This might occur among individuals within the firm, as well as competition with externals. This is a dark view of humanity's nature, but Kant viewed this natural unsocial tendency as also having positive attributes of stimulating us to overcome our laziness by seeking honor. It also has the negative aspect of seeking

\footnotetext{
11 The ancient philosophy, however, emphasized reflective revision and growth in virtue over one's life, a reflection and revision that ultimately leads to a happiness of contentment. (See Annas 1993, p. 332.) This requires, according to Aristotle, a "complete life with complete virtue." (NE, 1.x.).
} 
domination and property status over others whom we might dislike, but still cannot leave alone due to our inherent nature. We compete for positions, engage in rent seeking as a result of those positions, and may engage in the destruction of the creative efforts of others. ${ }^{12}$ The third formula of the CI, i.e., pursuit of a moral community, is aimed at redirecting our negative social passions (or inclinations) for gaining power over others for the purpose of using others as tools solely towards our own selfish ends, and not the ends of those so used. In particular, this unsocial power may be of a coercive nature, one that exploits the fear of others to make them pliable tools.

Kant's analysis is particularly relevant for the managerial ambition of honor, a particularly addictive ambition that seeks the good opinion of others. (See Wood 1999, p. 262, and in the original, Kant 1797, vol. 6, pp. 465-466.) Kant claimed that this ambition is linked to the psychology of self-worth associated with the desire to have others believe you are better than they. This desire for honor often manifests itself in haughtiness, or wanting others to despise themselves. An ethical self respect is not related to the opinion of others; it rests solely on a sense of dignity and absolute self-worth, and not on a sense of relative superiority. If, however, this sense of dignity is rooted in the pursuit of a moral community, especially for the business organization, then these antisocial tendencies of ambition, superiority and haughtiness should be modified, and subsumed into the ethical pursuit of self-worth associated with having moral goals rather than seeking superiority. When we recognize a friend of virtue, we honor the other, and through reflecting on the other's moral character, we might overcome the tendencies of seeking superiority or haughtiness.

Kant argued that failed ambition particularly leads to self degradation, and antagonism towards one's successful competitors in the struggle for the illusory superiority. Since ambition is perceived as a goal with an indefinite time dimension for achievement, one is likely to continually perceive some degree of failure in that one never (or seldom) achieves sufficient relative superiority. Pursuit of a moral community, however, is always perceived as an ideal continuously sought, but a journey without end. Success along its path generates self respect rather than any sense of superiority or inferiority. Whereas ambition is likely to solicit emotions of envy, and its associated attempts to frustrate the happiness of others, the pursuit of the moral community motivates the opposite, i.e., the will to assist others in pursuing their proper ends. Envy follows from our tendency to consider ourselves as happy only when we believe ourselves better off than others. ${ }^{13}$ This

\footnotetext{
12 "Rent seeking" in this context means seeking to receive compensation due to position rather than effort.
}

includes climbing the corporate ladder perhaps by achieving the demise of others through back-stabbing strategies. Envy often involves gloating over the misfortunes of others, and can lead to cruelty and meanness. Pursuit of the moral community redirects agents away from these tendencies. (See Wood 1999, p. 264, and Kant 1797, vol. 6, pp. 458-459.)

Kant also analyzed friendship in the context of morality. He perceived friendship as the only relationship based upon our natural needs that requires morality for its sustenance. (See Kant 1797, vol. 6, p. 471.) (Note that Aristotle's and Kant's views on friendship are notably similar on this point.) This notion of friendship should be sufficiently broad to incorporate our business relations including business associates outside our immediate establishment. All of these relations are also based on our natural needs, and demand morality if they are to be sustained. Kant's three forms of friendship, (1) need, (2) taste, and (3) disposition (a disposition to recognize our neighbors as friends) all apply to our business relations. To be sustained, each of these categories

- requires that we participate in the development and enjoyment of other's well being through our morally good will,

- arises from our general need to overcome our unsocial nature because of our survival need for social interaction, and

- usually involves certain actions of reciprocity since friendship thrives on (but does not absolutely require) differences in capacities and personalities so that we naturally contribute to one another. (See Kant 1797, vol. 6, pp. 470-474.)

To Kant, moral friendship was not merely an ideal; it exists, although rarely. Our "duty to oneself as well as to others is to not isolate oneself but to use one's moral perfection in social intercourse." (1797, vol. 6, pp. 472-473) This is also an Aristotelian concept presented in the form of a duty (imperfect duty as explained below). The "byproducts" of these friendly actions are "to create a beautiful illusion resembling virtue that is not deceptive" since all understand the nature of these actions. ${ }^{14}$ Here Kant suggests that the illusion of the ideal is sufficient to be practical.

"Affability, sociability, courtesy, hospitality, and gentleness (in disagreeing without quarreling) are,

\footnotetext{
13 Aristotle (1976, 1168 b 19) also addresses the issue of moral competition among virtuous people. He indicated the benign benefits that would result provided the competing parties have an appropriate sense of moral self-worth.

${ }^{14}$ I do not endorse the idea that these by products are only illusion. In business, these by products are definitely tangible.
} 
indeed, only tokens; yet they promote the feeling of virtue itself by a striving to bring this illusion as near as possible to the truth. By all of these, which are merely the manners one is obliged to show in social intercourse, one binds others too; and so they still promote a virtuous disposition by at least making virtue fashionable." (Ibid, vol. 4, p. 474)

"By making virtue fashionable" we understand the role of these virtuous characteristics in business where they can literally be profitable. They are the ideal style of business, a style that promotes commerce; a style of amicable and efficient norms both within the firm and for external dealings. This "fashion" is tangible and evolves due to what is most effective, but is rooted on effective sociability.

These demands of sustenance also surely describe the comparative advantage relations of the business firm. The business firm should be viewed as a union of both close and casual friends, with varying degrees of intimacy, which is formed for an economic profit-seeking purpose. The reciprocity referred to above consists of a readiness to engage in reciprocal benevolence in both effort and end goals, with the pursuit of a moral community being the ultimate reciprocal goal for each. Friendships of virtue, while envisioned in Aristotle's analysis as existing among the experienced and longer-lasting friends, also stimulates benevolence both among those experienced friends, but also benevolence towards others outside immediate friendships. This plays a role in the pursuit of the moral community in business.

Clarity among all those engaged as to the maxims required for a united (or harmonious) pursuit, are the ultimate concern of Kant's third formula. In particular, this pursuit requires clarity as to the juridical and other broad notions of morality applicable to business, and aimed at modifying the Kantian notion of unsocial sociability. In fact, the very notion of forming a business establishment as a union of friends (close or casual) can be viewed as an attempt to overcome this unsocial nature. The formation of our notions of applicable duty is then the purpose of the CI process (see below), and their implementation relies upon relations of virtue.

The above analysis partially indicates the purpose of the pursuit of a moral community and the aims of such a community within business, i.e., it incorporates friendships of both advantage and virtue, and presents an environment where the latter can be developed from the former. It also aims at developing a community of juridical duty and benevolence, both of which are fully explored below. In addition, the business friends embedded in the firm should achieve a high degree of clarity and commitment to the ethical structures of the firm-institutionalized procedures for diligently examining critical business decisions, evaluation of results with associated responses, and incentive-based rewards - and with this clarity and commitment, reinforcement of relations of virtue will occur. There is more about this dynamic development reviewed below.

\section{Some Recent Research in Business Friendship}

Although the research reviewed in this section does not directly concern what is termed relations of virtue, it does so indirectly, especially concerning how the virtue category can develop.

Ingram and Zou (2008) document the considerable volume of research on the tensions generated by business friendships, that is the tensions resulting from mixing professional and private lives (nepotism and cronyism that compromise business efficiency). Most, but not all, of this research indicates the harm caused by such friendships. Within the literature that indicates the positive benefits of business friendships, Baumeister and Leary (1995) and Fiske (2004) indicate that people seek social belonging through business friendships, and Tesser (1988) indicates the benefits of "basking in reflective glory" that results in the taking on of the attributes of moral business friends, a notion germane to friendships of virtue. From survey returns, Helliwell (2005) shows that trust in business friendships has a positive impact on job satisfaction, and other measures of physical wellbeing. This body of research that indicates positive benefits reinforces the notion that business people desire relations of virtue, and benefit from their development.

In addition, an array of other positive results is documented by this research. Friends imbedded in the same business demonstrate the following:

- Imbedded business friends discuss sensitive issues and new ideas that would not be shared otherwise. (See Sias and Cahill 1998, and Gibbons 2004.)

- Imbedded business friends share resources during crises. (See Krackhardt and Stern 1988.)

- Imbedded business friends make better career-related decisions. (See Kilduff 1992.)

- Imbedded business friends, and their firms, benefit from discussions of work problems. (See Fischer 1982.)

With respect to the afore mentioned exchange of specific business-knowledge, Blau (1964) shows that exchange of task-related knowledge is facilitated by friendship. Ibarra and Andrews (1993) shows that the empathy involved in friendship promotes knowledge transfers within the same organization. Uzi (1997) shows the advantage of businessembedded relationships in that friends have better capacity to understand each other, to communicate effectively, and are most effective transferring specific knowledge. 
Almeida and Kogut (1999) also documents this specifically for Silicone Valley business.

All of the research cited above supports the desirability notion of friendships in business, and the development of virtuous relations.

\section{The Pursuit of Business as a Moral Community, Friendships of Virtue, and Duty}

Kant (1785, vol. 4, pp. 402-403) posed a process for deriving the moral maxims necessary for practical living, i.e., the categorical imperative process (CI process), and claimed that his categorical imperative merely reflects common reasoning concerning moral principles, a reasoning captured by three specifications (formulae), each consistent with and necessitated by each of the other two. From his first specification, the formula of autonomy or of universal law, Kant showed, all our notions of duty, both perfect and imperfect follow. ${ }^{15}$ His second formula, the formula of respect for the dignity of persons, however, more clearly indicates those duties both to others and to ourselves. ${ }^{16}$

The second specification most clearly motivates a set of maxims we usually classify as duties although the interrelatedness of the three formulae implies that all duty can be derived from each of the three. (See Kant 1785, vol. 4, pp. 421, 429, 433). O'Neil (1995, pp. 114-115), however, terms the second formula "the formula on the ends-initself," and emphasizes its use as the foundation for duty, both positive and negative (explained below). This vision of duty is particularly applicable to business which requires a set of moral rules to function, both negative rules of prohibition and positive rules for diligent action. In particular, the second formula is generally interpreted as not only establishing prohibitions against the unethical actions of theft, fraud, coercion and the like, but also as requiring some degree of beneficence (positive duty), but also, as argued in this section, for diligence in managerial performance. Since the specification of this formula concerns treating both oneself and others as serving their own personal ends, and not merely serving as a means to another's ends, the positive duty side naturally requires practical limits on beneficence and diligence, limits Kant founded in "circumstance and inclination." (See Kant 1797, vol. 6,

\footnotetext{
15 "I ought never to act in such a way that I could not also will that my maxim should be a universal law." (Kant 1785, vol. 4, p. 421) These CI interpretations from the original German are from Sullivan (1994, p. 29).

16 "Act so that you treat humanity, whether in your own person or in that of any other, always as an end and never as a means only." (Kant 1785, vol. 4, p. 429)
}

pp. 452-454.) Below I indicate how friendships of virtue potentially extend those "circumstances and inclinations."

Without such practical limits, one could impoverish oneself, or so exhaust oneself in pursuit of beneficence and diligent performance, that this duty would largely interfere with obligations to oneself. If broad obligations of beneficence or duty were absolutely applied to business as though they were all perfect duties, i.e., those without practical limits, then business could not function in its primary role of rationing and utilizing resources so as to provide goods and services to the general public since these resources would be entirely used for beneficence. This is also true for positive obligations of diligent performance in that one must ration personal resources (time and concentrated effort) towards its most effective use in business without destroying personal health and wellbeing. Friendships of advantage and virtue can effectively help with this rationing. This issue is also explored in more detail below.

The third specification of the CI is the formula of legislation for a moral community: "All maxims that proceed from our own making of law ought to harmonize with a possible kingdom of ends." (Kant 1785, vol. 4, p. 433) Here legislating means self-legislating, i.e., establishing self-imposed maxims. Legislating a moral community can be viewed as the motivational formula for establishing and pursuing duty since this "kingdom of ends" is generally interpreted as a "moral community." (Kant 1785, vol. 4, p. 433.) As reviewed by Korsgaard (1996, p. 23):

"The human will must be seen as universally legislative. Each of us has a will that makes laws for itself as if for everyone. Since human beings together legislate the moral law, we form a moral community: a Kingdom of Ends. ... Each citizen takes his own perfection and the happiness of others as an end and treats every other as an end in itself. It is a community engaged in the harmonious and cooperative pursuit of the good." 17

To seek one's own perfection and the happiness of others as an end is likely to lead to Aristotle's friendships of virtue. ${ }^{18}$ This is an essential component of the moral community in that in order to seek the happiness of others without developing friendships would require a sort of callous isolation, which is not Kantian. To seek the happiness of others for the sake of others, and also to pursue duty for the sake of others, is to be friendly. This pursuit includes fulfilling juridical duty for sure, but it also includes more than this.

\footnotetext{
17 Also see Sullivan (1994, pp. 84-87) for a review similar to Korsgaard's.

${ }^{18}$ See Kant (1797, vol. 6, p. 393).
} 
For example, in Kantian analysis the pursuit of those duties that are consistent with the first and second formulae should be motivated by a desire to pursue a moral community. This is particularly applicable to business where laws, regulations, enforceable contracts, and numerous internal-to-the-firm rules, as well as external ethical and professional codes, are common. This nexus of maxims exists to establish business as a myriad of moral agreements ultimately within an overall social/moral economy. The general purpose of this overall institutional economy is ultimately the pursuit of the public good. This pursuit can only be effective if business generally desires to be moral. The motivation for following these maxims should therefore not merely be fear that if caught in violation of law and/or other rules, the negative consequences will be personal, but rather that any violation ultimately attacks the very potential for existence of any business as a moral community, i.e., the motivation itself must be moral.

As an example, consider the auditing accountant who because of a conflict of interest considers violating generally accepted rules. Such violations could lead to significant negative consequences for the firm at question, or even collapse of this firm. If the motivation for respecting these procedural rules is "I might lose my license to practice if I am discovered" (an egoistic motive), then believing that discovery has very small probability, the accountant has little incentive to not personally benefit at the expense of the other constituents of the firm. A commitment to pursue the interests of the moral community of this firm, however, requires a positive interest in the ends of other firm constituencies, of friends of virtue and of advantage. This positive empathetic-interest in others poses recognition of a risk of higher stakes than the fate of only the isolated individual, stakes that could be destroyed by moral violation. These are the high stakes at risk from moral depravation. Which motivation is therefore likely to be effective: the egoistic consequentialist motive, or the broader motive of service to society and friendships? I argue the latter, and hence the importance of the pursuit of the kingdom of ends as motivation.

Note that this is a consequentialist argument, which is typically perceived as non-Kantian since Kantian moral motivation is expressed as "respect for the moral law" without regard to consequences. This is the motivational point challenged in the "Moral Motivation" section above. To repeat the elucidation presented there, "respect" provides an incomplete argument for motivation; the third formula, however, provides the motive that is non-egoistic community-consequentialist. ${ }^{19}$ This is the non-religious motivation particularly applicable to business.

\footnotetext{
19 Wood (1999, pp. 301-302) also points out that consequentialist motivation is either egoistic or communal.
}

The ethical community of friends is one directed towards collective rational ends of which, according to Kant, there are two kinds: the ends of happiness, and the ends of morality. Happiness, however, can only be conditionally good as dependent upon morality, i.e., conditional upon the good will, and the good will pursues the moral community. A eudaimonist approach cannot aim for happiness unless it entails participation in a moral community, i.e., it must be subsumed by this moral pursuit. The communal-consequentialist motive can therefore serve the ends of morality even in Kantian terms.

People in general, and business people in particular, know that to live a flourishing life, where flourishing is defined broadly and philosophically, requires participation in a flourishing community, which in turn can only exist in a moral community. ${ }^{20}$ This eudaimonist argument is developed further below, but some reflection on Kantian implications needs reference here.

It has been effectively argued above that for establishing and pursuing our business duties, we must envision our ideal kingdom of ends as being the ideal moral business community. This conclusion results from a logical analysis. This, however, might be perceived as a eudaimonist argument, one that Kant argues against (1797, vol. 6, p. 377). He referred to this eudaemonist approach as the doctrine of happiness, and argued that “... if eudaimonism (the principle of happiness) is set up as the basic principle of eleutheronomy (the principle of the freedom of internal law giving), the result is euthanasia (easy death) of all morals." (Ibid, vol. 6, p. 378.) Is it possible that this desire for pursuit of a moral community is not eudaimonist?

We can recognize that this harmonious pursuit by its community members is a necessary requirement for that community to flourish to the extent possible, but surely we recognize that it is not a sufficient condition to assure happiness for each member, or even that it maximizes the probability of happiness for our individual self. One can view duty as possibly a sacrificial obligation necessary for the community to flourish, and not perceive that our duty originates in egoistic consequentialist reasons. We cannot help but know that we might indirectly benefit by our actions since we live in that community, but that particular knowledge need not lead to our motivation. In fact, we commonly observe duty being pursued from apparently non-egoistic motives, i.e., as members of a community, people may purse duty from motives of love and respect for fellow members, and certainly for developing friends of virtue. As stated more succinctly by Kant,

\footnotetext{
${ }^{20}$ Notions of flourishing, as used here, certainly incorporate material sustenance as well as societal coherence and support. Those economic communities that exhibit fraud, deception, coercion, and the like, inevitably implode.
} 
"The duty of love for one's neighbor can, accordingly, also be expressed as the duty to make others' ends my own (provided only that these are not immoral). The duty of respect for my neighbor is contained in the maxim not to degrade any other to a mere means to my ends (not to demand that another throw himself away in order to slave for my end)." $(1797 \text {, vol. 6, p. 450. })^{21}$

Does making the ends of others our own connote egoistic motivation if the process involves developing friendships of virtue? The degree of uncertainty might be large concerning the possible benefits, but developing friends constitutes a duty to oneself under the second formula of the CI. Since each of the three CI formulae imply, or are necessitated by the others, duty can be derived from each. Hill, however, establishes the notion that social duty (as different from duty-to-oneself as asserted by the second CI formula) is best expressed in the third formula:

“...I have sketched a reconstruction of Kant's idea of an inclusive commonwealth ("kingdom") united by common moral laws or principles. The members are conceived as both lawmakers and subjects. They each have their own set of ends but in legislating they abstract from personal differences. They legislate as rational and autonomous, and so they make only laws they can justify to each other. As legislators they respect humanity in each person as an end in itself, and so they are guided and constrained by all the values and precepts inherent in this fundamental ideal. As a formulation of the Categorical Imperative, the principle tells us always to act in accord with a possible kingdom of ends. Various supplementary ideas are needed to bring this abstract model down to real-world conditions where, for example, local conditions vary and people are often partisan, weak, corrupt, and divided. For the most part we should expect that only very general and defeasible principles can be justified as universal. These would need to be applied to various historical circumstances in light of more specific information. The ideal is to find well-grounded principles that all reasonable autonomous people would endorse; but because disagreements in applying principles are to be expected, as a practical matter the best we can do is to take ideas here as guide for conscientious judgement and choice rather than a sure path to moral truth." (Hill 2012, p. 81)

\footnotetext{
21 This is a Kantian passage that fully expresses the second formula's foundation for duty. For duty of virtue based upon respect, further see Kant (1797, vol. 6, p. 462).
}

The well-grounded principles ... endorsed by all reasonable autonomous people are the foundation of business, and they certainly include developing relations of virtue for the reasons reviewed above. These principles declare morality in business interactions, and without which economic failure is inevitable. Disagreements are surely common in business, but the well-grounded principles establish conscientious judgement as a path to moral choice. It is this conscientious judgment that is strengthened by having the second selves. This occurs because of comparisons with, and learning from one another, and this should especially occur within the necessary intense and sustained relations of business.

It must be recognized that understanding, acceptance, and consistent pursuit of these duties within business requires sufficient social discourse as should be facilitated by relations of virtue. (See Kant 1793, vol. 8, pp. 146-147. This is particularly emphasized by Wood 1999, Chap. 9, Sect. 4.) This should especially be so among management, between management and employees, and to a lesser extent between management and other stakeholders. This open discourse, particularly among virtuous relations, promotes collective development of agents' rational powers, and commitment to their use. This acceptance requires an understanding of the duties' necessity for the sustainability of the organization, an understanding that can only come from this required communication largely among friendly relations. In fact, this required communication is itself an ethical duty of managerial leadership just as friendship is a Kantian duty. We are used to thinking of business management as autocratic, but the success of the firm requires a commitment to duty from those who participate, and this ideal cannot be expected from a servile following, but can be expected from a friendly following of committed agents. The ideal requires that all constituents understand and follow the generally accepted duties that constitute pursuit of the moral community. A lack of clarity among constituents concerning this pursuit is likely to lead to egoistic motivation and possible moral failure. These are points also suggested by Bowie (1999, pp. 88-89).

A fully-moral community clearly requires that all are committed to both perfect and imperfect duties, even though the latter has limits due to individual circumstances and virtuous inclination. (See Korsgaard 1996, p. 20.) It is more realistic, however, to expect that the latter classification of duty should be stronger within certain arrangements where agents are more knowledgeable about the needs of other participants, perhaps because of closer connections, perhaps because of developed friendships. This might occur among friends imbedded in the same firm rather than in the broader more impersonal relations where people are distant from each other and perhaps less knowledgeable about the needs of other participants. We could assert this principle as a duty from familiarity: The more familiar (knowledgeable) agents are about the needs 
of each other, and about how to contribute to those needs, the wider the degree of imperfect duty of beneficence between them. ${ }^{22}$

The above proposition is founded on the notion of effective use of the agent's resources: time, psychological commitments, and talents; but it also recognizes the interpersonal knowledge differences. Any notion of the circumstances facing an agent with respect to an obligation of diligent effort should be based on the most effective use of these resources, and knowledge partly determines the effectiveness of this resource use.

Positive duties are clearly necessary for promoting the interests of those both internal and external to the firm. In Kantian analysis, the self-worth of agents motivates them to "pursue their own morally permissible welfare and happiness, but also to promote those of others." (Sullivan 1997, p. 156.) These "others" should certainly include our friendly business relations especially those of virtue. One suspects that self-worth, as needed to overcome our unsocial sociability, would suffer greatly if the promotion of the welfare and happiness of our friendly relations were lacking. In the context of business, we note that our relations are expressions of mutual dependence aimed at fulfilling mutual needs especially within the firm. We can assert this principle as a duty from mutual dependence: Mutual respect requires that both sides of any business interaction are not only interested in their own ends, but are also interested in enabling others to achieve their ends, i.e., "we make ourselves an end of others" and "through our will we make others our ends as well. The happiness of others is therefore an end that is also a duty." (Kant 1797, vol. 6, p. 393.)

The simple question, "What can I do to help?" offered among business friends of either advantage or virtue, expresses the principle stated above. This question could even be used as part of a description of either a friendship of advantage or of virtue. If we combine the duty from familiarity with the duty from mutual dependence, then we conclude that business transactions between agents who are more knowledgeable about each other's needs (perhaps because they are more familiar), should have an expectation of positive duty with limitations that are wider the greater the degree of knowledge. This obligation of beneficent assistance should be stronger the more familiar (or knowledgeable) the agents are about the obligations and needs of each other, and this knowledge or familiarity is largely determined by the nature of the particular business relation in question. Those of friendship, especially virtuous friendship, must have wider limits concerning these obligations towards one another.

\footnotetext{
${ }^{22}$ Kant (1797, vol. 6, pp. 451-452) addresses the issue of benevolence as associated with "closeness," but he does not address the issue of the connection between "knowledge" and benevolence except tangentially. (See Sullivan 1997, p. 98.).
}

In Kantian analysis, however,

“... human beings have a duty of friendship.-But it is readily seen that friendship is only an idea (although a practically necessary one) and unattainable in practice, although striving for friendship (as a maximum of good disposition toward each other) is a duty set by reason, and no ordinary duty, but an honorable one." (Kant 1797, vol. 6, p. 470.)

It appears that Kant is somewhat pessimistic concerning the moral heights that friendships of virtue might reach. Those with similar views (certainly darker than Aristotle's) appear likely to pose philosophies that rely on juridical duty for proper behavior among fellow mangers. Those with more optimistic views of humanity (more in line with Aristotle's) appear likely to include both juridical and broader notions of imperfect duty for managerial behavior.

For business to properly serve society, at minimum participants must fully conform to juridical requirements. Businesses based on fraud and deception could not possibly be viewed as optimally meeting society's needs since these organizations would interfere with the worthy ends of participants, and therefore would implode in that they would be abandoned. The more participants perceive the probability of encountering outright fraud or even partial deception concerning the product, service, or payment, the more those participants would abandon those institutions in question. Furthermore, without the commitment to pursue a moral community, we might not expect agents to fully conform to these negative duties, although fear of retribution, or ostracism if caught, might motivate a considerable degree of conformance depending upon the probability of discovery. (The auditing accountant example presented above illustrates this principle.) We must, however, ask whether purely juridical constraints would be more likely followed by a community with at least some virtuous friends as compared to a community lacking such relations? The answer is obvious. There are two reasons we answer "yes" to this question. First, relations of virtue reinforce a developed sense of duty and conscience among those touched by these friendships. Second, the disappointment over lapses, especially of the juridical sort, would result in ostracism of the violators from the community, an unwelcomed ostracism from friends. These views are expanded in the section below.

\section{Relations of Virtue and Avoidance of Evil in Business}

This section examines the proposition that the avoidance of evil in business is substantially facilitated by the development of relations of virtue within management. As a result, 
this development should be an integral component of the pursuit of a moral community.

Kant's most striking anthropological doctrine is that human nature contains a radical (extreme) propensity to evil, an innate propensity to make choices against the moral law. (See Wood 1999, pp. 283-284.) Kant explains three types of human evil:

1. The total depravity of willful avoidance of the moral law,

2. An impurity that requires incentives to initiate one's moral duty, and

3. An impurity that requires incentives to fully complete one's duty. (See Kant 1793, vol. 6, pp. 29-30.)

According to Kant, evil is a product of our unsocial sociability, of ambition and envy as reviewed in the "Classic and Recent Applicable Notions of Friendship, Sociability, and Moral Community" section above. The pursuit of a moral community, including virtuous relations, can be the preventative of evil. As in the quote from Hill concerning "well-grounded principles" presented above, pursuit of the $\mathrm{K}$ of $\mathrm{E}$ can theoretically admit a knowledge of and commitment to duty that counters our unsocial tendencies. This can allow both the formation and sustenance of business as indicated in the next section, but for the immediate problem at hand, we should focus on Kant's second and third types of evil since perhaps they appear endemic to business.

A market-system economy is based upon the price system for allocating resources. This is a monetary incentive system, and there are practical reasons for this. Monetary compensation expresses general purchasing power, whereas other business compensation (flexible schedules, titles, product, position advancement) are not as generally acceptable, although in some cases they are acceptable as incentives, but usually more difficult to negotiate. Even in the human resource market that is internal to the firm (as well as external human resource markets), monetary compensation is the norm. The relevant question is whether compensation is necessary for managers or other employees to seriously pursue their duty, especially imperfect duties? Monetary compensation, however, does communicate to employees the importance the firm places on the performance of duty, i.e., rhetorical commitment without compensation may be perceived as not being a serious commitment by the firm.

If widely present in the firm, however, Kant's second and third types of evil (those based on incentives for pursuing or completing duty) hardly describes a moral community. It describes, rather, a community of egoistic consequentialists with all its incentive flaws. Kant's ethical community described in Religion Within the Boundaries of Reason (1793-1994), however, is the completion of the
Kingdom of Ends concept first described in Fundamentals (1785) and repeated in the Metaphysics (1797). This concept of the moral community goes beyond one in which negative coercive-type laws are obeyed by all. It involves a union under norms of virtue that cannot be established by legislation, but requires virtuous disposition of all. (See Kant 1793, vol. 6, p. 94 and Allison 2012, p. 222.) It forms a practical pursuit for humanity even though the actual goal is unattainable. It cannot even be pursued by the individual in isolation since, as described above, it requires overcoming social evils not just individual imperfections. Kant argued that all must be virtuous in order for each individual to be fully virtuous. (Kant 1793, vol. 6, pp. 93-102.) It should be clear, however, that a business community of developed virtuous relations, with its positive reinforcement and desires for inclusion of all members, is also likely to provide incentives to avoid evil and pursue the moral community. Kant terms this "an impurity" due to the requirements and provisions of incentives. (See Kant's second third types of evil listed above.) Can this conflict be resolved?

Kantian ethics require people "to unite their ends into a single, reciprocally supporting teleological system, or realm. The ideals of Kantian ethics are autonomy, equality, and community." (Wood 1999, p. 335.) These ideals can only be pursued as a unit; to fail to pursue one means failure to pursue the other two. This view concerns the natural conflict between the individual and a rational striving for an agreeable community. "It is about the process of enlightenment enabling us to form the idea of the laws and principles of such a community, and about the hope that gradually, through the historical progress of reason, we may overcome the conflict that is natural to us and make progress towards an ideal realm of ends on earth." (Ibid, p. 335.)

“.... The proper model for that collective pursuit is neither a closed society based on pious adherence to tradition nor an ever-shifting nexus linking people solely through self-interest, strategic bargaining, and exploitation. Real solidarity between mature human beings can grow only from their shared commitment to universal principles that are given content and universal validity by an ongoing process of free, enlightened communication." (Ibid, p. 336.)

This "shared commitment" is a description of virtuous relations. Such a shared commitment to universal principles can certainly be a vision for an ideal business, but in Kantian analysis, this worldly ideal is perhaps too extreme. Businesses are combinations of worldly men.

“....Men ... mutually corrupt one another's moral predispositions. Despite the good will of each individual, because they lack a principle which unites 
them, men abandon, through their dissensions, the common goal of goodness and, just as though they were instruments of evil, expose one another to the risk of falling once again under the rule of the evil principle." (Kant 1793, vol. 6, p. 97.)

Again the question begged is "Can we find a principle that can unite us within business?"

"But because the highest moral good cannot be achieved merely by the exertions of the single individual to unite into a whole directed toward the same goal, that is into a system of well-disposed men ... the idea of such a whole as a universal republic based on laws of virtue is an idea sharply distinguished from all moral laws which concern what we know to lie in our power. It involves a union of which we do not know whether, as such, it lies in our power or not. Hence this duty is distinguished from all others both in kind and in principle." (Kant 1793, vol. 6, pp. 98-99.)

The principle sought is the pursuit of virtuous relations among business associates. A business can, and certainly should, be a juridical community where all coercive laws and norms are obeyed. The question is "Can such a business also be a community of virtue?" As stated in "The Pursuit of Business as a Moral Community, Friendships of Virtue, and Duty" section, this requires that both perfect (negative) and imperfect (positive) duties be pursued under the motivation of pursuit of a moral community. This latter pursuit implies the former pursuit. To be pure, such a motivation must be untainted from monetary or other incentives. Still, to more properly answer the above question, we best recognize that a business organization is a nexus of perfect and imperfect duties, the latter including not only beneficence, but also all of the managerial obligations that have practical limits which themselves are widened by the development of virtuous relations.

For example, all obligations of due diligence have practical limits. Due diligence is also a moral obligation of management owed to all stakeholders. The relevant question for managerial agency (agents who represent the interests of owners) concerns where these limits are drawn. At what point do we have sufficient data and analysis concerning a proposed capital project in order to make an appropriate decision, or perhaps concerning an employee development proposal, or newly proposed outsourcing strategy? There are practical limits to expenditures of managerial time, effort, or financial resources on all managerial efforts whether they involve traditionally defined beneficence or more broadly defined imperfect responsibilities. As stated above, full managerial pursuit of a moral community requires these expenditures up to the point of practical limits, but the setting of those limits are still at issue, and therefore the extent of the moral obligation. Here we get to the crux of the matter. Immediate diligent effort is not the same as a development of expertise, perhaps of the specific knowledge, but also the general knowledge required for the effective managerial decision making. This expertise development is itself a long-run obligation of diligence. Relations of virtue provides a long-run dynamic that potentially facilitates this development of expertise. How? In a virtuous friendly way, senior management assists those in junior positions through direction, and senior managers assist and reflect each other's efforts. Knowledge makes diligence easier and more effective, and virtuous relations facilitate development of knowledge, both firm specific and general.

\section{Relations of Virtue and the Pursuit of a Moral Community}

In an effort separate from his two major publications concerning morals (1985 and 1797), Kant (1793, vol. 6, pp. 98-99) argued a religious basis for pursuing a moral community, that such a community could only be pursued through a visible church. I argue, however, that business organizations also aspire to being moral. We can view a secular organization as pursuing a moral community, and this is especially practical within business. It is not a visible church that should be pursued in this context, but a business community that fosters virtuous relations. Business firms potentially qualify as secular visible institutions ideally constructed to aspire to being moral communities facilitated by friendships of virtue as developed from friendships of advantage.

The explicit and implicit contractual structure of a business, its standard procedures, internal controls, employee management specifications, external communication controls, contracts with suppliers, etc., all express its moral obligations, but beyond these specifications, the company's established behaviors with constituencies, particularly its fairness in negotiations with constituencies, define the business' moral content. These behaviors define the company's degree of pursuit of a moral community. These declared procedures and precedents of shared commitments to universal principles established through ongoing enlightenment communication among virtuous business associates are all aimed at counteracting our tendency towards mutual corruption. Such is the potential of any business organization. This is the meaning of having a motivation of pursuit of a moral community, but such a pursuit is centered on internal and external relations of virtue, i.e., internal and external to the firm. 
Acknowledgments This study was entirely unfunded by any grant or other source.

\section{Compliance with Ethical Standards}

Ethical approval This article does not contain the results of any studies with human participants or animals performed by the author.

Open Access This article is distributed under the terms of the Creative Commons Attribution 4.0 International License (http://crea tivecommons.org/licenses/by/4.0/), which permits unrestricted use, distribution, and reproduction in any medium, provided you give appropriate credit to the original author(s) and the source, provide a link to the Creative Commons license, and indicate if changes were made.

\section{References}

Allen, P. (2011). Idea man: A memoir of the cofounder of microsoft. New York: Penguin Group US.

Allison, H. E. (2012). Essays on Kant. Oxford: Oxford University Press.

Almeida, P., \& Kogut, B. (1999). Localization of knowledge and the mobility of engineers in regional networks. Management Science, 45(7), 905-917.

Annas, J. (1993). The morality of happiness. New York: Oxford University Press.

Arendt, H. (1978). The Life of the Mind, Hancourt, Inc.: New York.

Aristotle. (1976). The ethics of Aristotle: Nicomachean ethics (J. H. K. Thomson, Trans.). London: Penguin Books.

Baime, A. J. (2014). Arsenal of democracy. New York: Houghton Mifflin Harcourt.

Baumeister, R. F., \& Leary, M. R. (1995). The need to belong: Desire for interpersonal attachments as a fundamental human motivation. Psychological Bulletin, 117, 497-529.

Blau, P. M. (1964). Exchange and power in social life. New York: Wiley.

Bowie, N. E. (1999). Business ethics: A Kantian analysis. Malden, MA: Blackwell.

Brennan, J. (2012). For-profit business as a civic virtue. Journal of Business Ethics, 106(3), 313-324.

Brickley, J. A., Smith, C. W, Jr., \& Zimmerman, J. L. (2007). Managerial economics and organizational architecture (4th ed.). New York: McGraw-Hill Irwin.

Cooley, D. R. (2002). False friends. Journal of Business Ethics, 36, 195-206.

Cooper, J. M. (1980). Aristotle of friendship. In A. O. Rorty (Ed.), Essays on Aristotle's ethics (pp. 301-340). Berkeley, CA: University of California Press.

Fischer, C. S. (1982). What do we mean by "Friend": An inductive study. Social Network, 3, 287-306.

Fiske, S. T. (2004). Social beings: A core motives approach to social psychology. New York: Wiley.

Gibbons, D. E. (2004). Friendship and advice networks in the context of changing professional values. Administrative Science Quarterly, 49(2), 238-262.

Helliwell, J. F. (2005). Well-being, social capital and public policy: What's new? Paper presented at Annual Meetings of the Royal Economic Society, Nottingham, UK.

Hill, T. E. (1992). Dignity and practical reason in Kant's moral theory. Ithaca, NY: Cornel University Press.
Hill, T. E. (2012). Virtue, rules and justice. Oxford: Oxford University Press.

Ibarra, H., \& Andrews, S. B. (1993). Power, social influence, and sense making: Effects of network centrality and proximity on employee perceptions. Administrative Science Quarterly, 38(2), 277-303.

Ingram, P., \& Zou, X. (2008). Business friendships. Research in Organizational Behavior, 28, 167-184.

Jensen, M. C. (2000). A theory of the firm. Cambridge, MA: Harvard University Press.

Josephson, M. (1962). The robber barons. New York: Harcourt Brace Jovanovich.

Kant, I. (1784). Idea for a universal history with cosmopolitan intent. In A. W. Wood (Ed.), Basic writings of Kant. Modern Library Classics (2001). New York: Random House Inc.

Kant, I. (1785). Fundamental principles of the metaphysics of morals. In A. W. Wood (Ed.), Basic writings of Kant. Modern Library Classics (2001). New York: Random House Inc.

Kant, I. (1793-1794). Religion within the limits of reason alone. In A. W. Wood (Ed.), Basic writings of Kant. The Modern Library Classics (2001). New York: Random House Inc.

Kant, I. (1797). The metaphysics of morals (M. Gregor Ed.). Cambridge: Cambridge University Press. Reprinted in 2012.

Kilduff, M. (1992). The interpersonal structure of decision making: A social comparison approach to organizational choice. Organizational Behavior and Human Decision Processes, 47(2), 270-288.

Koehn, D. (1998). Can and should businesses be friends with one another and with their stakeholders. Journal of Business Ethics, 17(15), 1755-1763.

Korsgaard, C. M. (1996). Creating the kingdom of ends. Cambridge: Cambridge University Press.

Krackhardt, D., \& Stern, R. N. (1988). Informal networks and organizational crises: An experimental simulation. Social Psychology Quarterly, 51(2), 113-140.

Lager, F. (1994). Ben and Jerry's: The inside scoop. New York: Crown Publishers.

McCullough, D. (2015). The Wright Brothers. New York: Simon and Schuster.

O'Neill, O. (1995). Constructions of reason: Explorations of Kant's practical philosophy. Cambridge: Cambridge University Press.

Rich, B., \& Janos, L. (1994). Skunk works. Boston: Little Brown and Company.

Sias, P. M., \& Cahill, D. J. (1998). From coworkers to friends: The development of peer friendships in the workplace. Western Journal of Communication, 62(3), 273-299.

Smith, A. (1759). The theory of moral sentiments In D. D. Raphael \& A. L. Macfie (Eds.). Indianapolis, IN: Liberty Fund, 1982.

Smith, A. (1776). An inquiry into the nature and causes of the wealth of nations. In R. H. Campbell \& A. S. Skinner (Eds.). Indianapolis, IN: Liberty Fund, 1982.

Sommers, M. C. (1997). Useful friendships: A foundation for business ethics. Journal of Business Ethics, 16(12), 1453-1458.

Stewart, J. A. (1892). Notes on the Nicomachean ethics (p. 392). Oxford: Oxford University Press.

Sullivan, R. (1994, 1997). An introduction to Kant's ethics. Cambridge: Cambridge University Press.

Taylor, C. C. W. (1995). Eudaimonia. In T. Honderich (Ed.), The Oxford companion to philosophy (p. 252). Oxford: Oxford University Press.

Taylor, C. C. W. (2000). Eudaimonia. In Concise Routledge encyclopedia of philosophy (p. 260). New York: Routledge.

Tesser, A. (1988). Toward a self evaluation maintenance model of social behavior, edited by L. Berkowitz. Advances in Experimental Social Psychology, 21, 181-227. 
Uzi, B. (1997). Social structure and competition in interfirm networks. Administrative Science Quarterly, 42(2), 417-418.

White, M. D. (2010). Adam Smith and Immanuel Kant: On markets, duties, and moral sentiments. Forum for Social Economics, 39(1), 53-60.
White, M. D. (2011). Kantian ethics and economics. Stanford, CA: Stanford University Press.

Wood, A. W. (1999). Kant's ethical thought. Cambridge: Cambridge University Press. 